\title{
An Analysis on Serious Games and Stakeholders' Needs for Vocal Training Game Development
}

\author{
Xiaopeng Yang ${ }^{a}$, Edwina Dwi Sadika ${ }^{b}$, Gradiyan Budi Pratama ${ }^{c}$, Younggeun Choi ${ }^{b}$, Yu-Kyung Kim ${ }^{\mathrm{d}}$, Ji-Yun Lee , \\ Yunju Jo ${ }^{\text {gh, }}$, Giwook Kim ${ }^{\text {h,i }}$, Jin-Kook Lee ${ }^{\mathrm{i}}$, Min-Jung Yu ${ }^{\mathrm{f}}$, Myoung-Hwan Ko ${ }^{\mathrm{ghh,i}}$, Heecheon You \\ ${ }^{a}$ School of Digital Media, Jiangnan University, Wuxi, China \\ ${ }^{b}$ Department of Industrial \& Mangement Engineering, Pohang University of Science and Technology, Pohang, Korea \\ 'Department of Industrial Engineering, Bandung Institute of Technology, Bandung, Indonesia \\ ${ }^{d}$ Department of Speech Language Pathology, Suncheon Jeil College, Suncheon, Korea \\ e Department of Speech Language Therapy, Jeju International University, Jeju, Korea \\ ${ }^{f}$ Commercializations Promotion Agency for R\&D Outcomes, Seoul, Korea \\ ${ }^{8}$ Graduate Program in Speech-Language Therapy, Chonbuk National University, Jeonju, Korea \\ ${ }^{h}$ Research Institute of Clinical Medicine of Chonbuk National University-Biomedical Research Institute of Chonbuk National University Hospital, \\ Jeonju, Korea \\ iDepartment of Physcial Medicine and Rehabilitation, Chonbuk National University Medical School, Jeonju, Korea
}

\author{
Correspondence: Heecheon You, PhD \\ Department of Industrial \& Mangement \\ Engineering, Pohang University of Science and \\ Technology, 77 Cheongarm-ro, Nam-gu, Pohang, \\ 37673 , Korea \\ Tel: +82-54-279-2210 \\ Fax: +82-54-279-2870 \\ E-mail: hcyou@postech.ac.kr
}

Co-correspondence: Myoung-Hwan Ko, $\mathrm{MD}, \mathrm{PhD}$ Department of Physical Medicine and Rehabilitation, Chonbuk National University Medical School, 20 Geonji-ro, Deokjin-gu, Jeonju, 54907, Korea

Tel: +82-63-250-1795

Fax: +82-63-254-4145

E-mail: mhko@jbnu.ac.kr

Received: July 9, 2019

Revised: August 10, 2019

Accepted: August 27, 2019

This research was jointly supported by the Biomedical Research Institute Fund, Chonbuk National University Hospital, the National Research Foundation (NRF) of Korea funded by the Ministry of Science, ICT, and Future Planning (MSIP) (No. NRF-2018R1C1B5047805; No. NRF2018R1A2A2A05023299), and the Ministry of Trade, Industry, and Energy (No. 10063384; No. R0004840, 2017)
Objectives: The present study intended to identify the needs and development directions of a serious vocal training game for better motivation and commitment of patients with voice disorder to voice therapy. Methods: A literature review, a survey of stakeholders' needs, and a benchmarking analysis of three vocal training games (Visi Pitch, Dr. Speech, and Vox System) was conducted. Results: From the literature review, thirteen game user experience scales (usability, narratives, play engrossment, enjoyment, creative freedom, audio aesthetics, personal gratification, social connectivity, visual aesthetics, accuracy, customization, game analytics, and therapy continuity) were identified for vocal training games and then applied to evaluation of the existing games. From the user experience scales, features not commonly implemented in the existing games include creative freedom (average satisfaction score, 2.5 to 4.3 out of 7 ), social connectivity (2.4 to 4.4 ), therapy continuity (1.7 to 4.7), and customization (2.5 to 5.0). Conclusion: The user experience scales would be of use to assess vocal training games, and new serious games need to be developed to complement the existing games in terms of the four scales found relatively lacking.

Keywords: Serious game, Voice therapy, Vocal training game, User experience

Voice disorders are characterized by the abnormality of pitch, loudness, quality of sound, and/or duration in voice production; resulting in a significant need of therapy (Ziegler \& Hapner, 2013).
The estimated prevalence of voice disorders among US young adults aged 24-34 years is 6\% (Bainbridge, Roy, Losonczy, Hoffman, \& Cohen, 2017), and that among US children aged 3-17 years is 1.4\% 
(Black, Vahratian, \& Hoffman, 2015). However, the percentage of patients with voice disorders seeking treatment is $0.98 \%$ (Cohen, Kim, Roy, Asche, \& Courey, 2012), indicating most individuals with voice disorders do not receive treatment. Among the treatment-seeking population, the prevalence of voice disorders is reported to be higher in female adults than male adults, with an odds ratio of 1.5 (Martins et al., 2016; Roy, Merrill, Gray, \& Smith, 2005), male children than female children (Carding, Roulstone, \& Northstone, 2006; Martins et al., 2016), and elderly adults (4.8\%29.1\%) than children (1.4\%-6\%) (de Araújo Pernambuco, Espelt, Balata, \& de Lima, 2015).

Voice therapy can help patients with voice disorders acquire self-confidence, independence, and social skills by improving their voice production. Voice therapy is conducted for the training of voice production in controlling voice tone (pitch), intensity (loudness), and breath (continuity) (Saz, Yin, Lleida, \& Rose, 2009). Conventionally, voice therapy is conducted based on mechanization (Navarro-Newball et al., 2014) and therefore it is hard to maintain a patient's motivation and attention during the therapy session, unavailable at home, and limited by the subjective evaluation of a therapist.

Serious games can be an effective assistance in voice therapy by motivating patients with voice disorders through the accomplishment of fun tasks. Serious games have been developed for purposes more than mere entertainment and increasingly applied in education, training, and healthcare; for example, some healthcare purposes of serious games include health monitoring, diagnosis, treatment, therapy, and rehabilitation (Wattanasoontorn, Boada, García, \& Sbert, 2013). Therapists and patients have provided positive responses to the application of serious games to speech therapy (Grossinho, Cavaco, \& Magalhães, 2014; Navarro-Newball et al., 2014; Vicsi, 1995). Examples of speech therapy games include Articulation Station (Little Bee Speech, USA), Dr. Speech (Batalla et al., 2014), Speech Mirror (CluSoft, Seoul, Korea), Talking to Teo (Navarro-Newball et al., 2014), Visi-Pitch (Perry, Ingrisano, \& Scott, 1996), and Vox System (RS Care Systems, Daegu, Korea). Shtern, Haworth, Yunusova, Baljko, and Faloutsos (2012) reported that serious games increased patients' motivation and sustainment in speech therapy compared with the conventional therapy by providing immediate feedback and intuitive gaming scenarios.
Furthermore, it is reported that the majority (78\%) of patients treated for speech therapy were children aged 12 or under (Pyo, 2013) and the majority (97\%) of speech therapy treatments with children patients are practiced in clinical environments (Choi, 2013). Though the number of commercial serious games has been increasing, the percentage of speech therapy-related games among all serious games is $0.93 \%$ (Wattanasoontorn et al., 2013), indicating the needs of developing more serious games for speech therapy.

An integration of emerging technologies, including smart devices and virtual reality technologies, with conventional speech therapy programs has been explored with careful considerations. Kim et al. (2017) and Lee, Park, and Yoo (2019) developed smartphone based programs for the continuity of voice therapy from clinical to real-life environments. Da Silva, Fernandes, and Grohmann (2015) proposed an augmented reality based interactive system which assists interventions with children with autism spectrum disorders performed by speech therapists and supports parents' participation in the interventions. Kim and Kwon (2018), Kim, Kwon, Kwon, and Paeng, (2019), and Park, Kim, Lee, Bae, and Kwon (2019) examined the effects of augmented reality based language therapy programs on the intervention of children with language disabilities. Evidence of the transfer of functional communication skills acquired during virtual environments to real-world situations supports the potential of the emerging technologies of the fourth industrial revolution era in the field of speech-language pathology. However, safety and ethical issues such as cyber sickness and cyber security need to be carefully considered during the research and practice of virtual reality technologies (Bryant, Brunner, \& Hemsley, 2019).

The present study intended to identify the needs and development directions of a vocal training game to better support voice therapy through a systematic analysis of stakeholders' needs and existing games. Game user experience scales were identified by a literature review and then a questionnaire was prepared based on the identified game user experience scales for the evaluation of vocal training games. Game user experience scales lacking in the existing games were identified and a benchmarking of existing games was performed to identify key features to be applied to new serious game development. 


\section{METHODS}

\section{Identification of Game User Experience Scales}

A literature review was conducted to identify user experience scales for evaluation of vocal training games. Articles of serious games for speech therapy were systematically searched by keywords including 'speech therapy' and 'serious game' and screened by title, abstract, and content, resulting in 13 articles for review.

\section{Benchmarking of Existing Vocal Training Games}

Several commercial serious games such as Visi Pitch (Pentax Medical, Montvale, NJ, USA), Dr. Speech (TigerDRS Inc., Seattle, WA, USA), and Vox Systems (RS Care Systems, Daegu, Korea) providing vocal training functions are available on the market. These three games are often used by clinicians and therapists as a supporting tool for conducting voice therapy. Their weaknesses and strengths were analysed to identify key features applicable to vocal training game development.

\section{Survey of Stakeholders' Needs}

A questionnaire survey was conducted to analyze the needs of stakeholders for vocal training games. Eighteen speech therapists
(6 males and 12 females) having over 3 years of experience in voice therapy participated in the survey. The percentage of speech therapists who had used serious games for voice therapy for more than one year and that of the therapists who had used serious games for voice therapy more than once a week were $77.2 \%$ and $66.7 \%$, respectively. As for vocal training games the therapists found most effective based on their experience, Visi Pitch was selected most highly (42.1\%), followed by Dr. Speech (26.3\%) and Vox Systems (5.3\%). Lastly, children under the age of 12 years were found dominant $(77.8 \%)$ among the patients the therapists had provided for vocal training services.

The questionnaire in Appendix 1 consisting of 36 statements for 13 game user experience scales, with a 7-point Likert scale (' 1 ' for very dissatisfied and ' 7 ' for very satisfied), was used for speech therapists to evaluate a vocal training game that they had selected as most effective in vocal therapy based on their experience. The average satisfaction scores was calculated for each user experience scale by referring to Table 1 . User experience scales which were commonly lacking in existing vocal training games were identified from the survey evaluation results. In addition to the therapists' experience with the vocal training games, likes, dislikes, and suggestions for each game were surveyed. Patients with voice dis-

Table 1. Game user experience scales

\begin{tabular}{|c|c|c|}
\hline Scale & Description & Statement No. in Appendix 1 \\
\hline Usability & $\begin{array}{l}\text { The ease in which the game can be played with clear goals in mind and with minimal cognitive interferences or ob- } \\
\text { structions from the user interfaces and controls }\end{array}$ & $1-7$ \\
\hline Narratives & $\begin{array}{l}\text { The story aspects such as events and characters of the game and their abilities to capture the player's interest and } \\
\text { shape the player's emotions }\end{array}$ & 8,9 \\
\hline Play engrossment & The degree to which the game can hold the player's attention and interest & $10-12$ \\
\hline Enjoyment & The amount of pleasure and delight that are perceived by the player as a result of playing the game & $13-15$ \\
\hline Creative freedom & $\begin{array}{l}\text { The extent to which the game is able to foster the player's creativity and curiosity and allows the player to freely } \\
\text { express his or her individuality while playing the game }\end{array}$ & $16-19$ \\
\hline Audio aesthetics & The different auditory aspects such as sound effects of the game and how much they enrich the gaming experience & 20,21 \\
\hline Personal gratification & $\begin{array}{l}\text { The motivational aspects such as challenge of the game that promote the player's sense of accomplishment and } \\
\text { the desire to succeed and continue playing the game }\end{array}$ & $22-26,31$ \\
\hline Social connectivity & The degree to which the game facilitates social connection between players through its tools and features & 27,28 \\
\hline Visual aesthetics & The graphics of the game and how attractive they appeared to the player & 29,30 \\
\hline Accuracy & The accurate interoperation of the input device with the game contents & 32 \\
\hline Customization & The degree to which the parameters of the game are customizable to the player & 33 \\
\hline Game analytics & The extent to which the results of the game are managed and analyzed for effective training & 34,35 \\
\hline Therapy continuity & The extent to which treatment activities in a treatment facility can be practiced at home & 36 \\
\hline
\end{tabular}

Nine out of 13 game user experience scales were adopted from Phan, Keebler, \& Chaparro (2016). 
orders and their guardians were not included in the survey due to their limited experience in voice therapy games. The research protocol of the present study was approved by the Institutional Review Board at Pohang University of Science and Technology (No. PIRB-2016-E044).

\section{RESULTS}

\section{Game User Experience Scales}

A total of 13 scales presented in Table 1 were identified based on the review of 13 articles as those needed for the user experience attributes of vocal training games. Nine game user experience scales including usability, narratives, play engrossment, enjoyment, creative freedom, audio aesthetics, personal gratification, social connectivity, and visual aesthetics were adopted from the Game User Experience Satisfaction Scale (GUESS; Phan, Keebler, \& Chaparro, 2016). In addition to the nine GUESS scales, four scales including accuracy, customization, game analytics, and therapy continuity were added based on the review of the other articles (Cagatay, Ege, Tokdemir, \& Cagiltay, 2012; Faria et al., 2014; Grossinho et al., 2014; King, Davis, Lehman, \& Ruddy, 2012; Kostoulas et al., 2012; Lee, Kim, Yoo, \& Ko, 2015; Marache-Francisco \& Brangier 2016; Mayer, 2012; Navarro-Newball et al., 2014; Shtern et al., 2012; Vicsi, 1995; Wattanasoontorn et al., 2013). The statement numbers in Appendix 1 corresponding to each of the user experience scales are indicated in the last column of Table 1; the first 30 statements were adopted from the GUESS study by Phan et al. (2016) and the remaining 6 statements were prepared for the four newly added scales and by referring to related papers.

\section{Benchmarking of Existing Vocal Training Games}

Three vocal training games including Visi Pitch, Dr. Speech, and Vox System were compared to identify key features applicable to the development of a vocal training game with better features. Of the existing vocal training games, these three vocal training games were selected as most effective by the therapists in the survey of the present study by a relatively high margin. All the vocal training games provide the training functions of voice production in vocal continuity, loudness, and pitch; and allow therapists to set the target level, training time, and repetition of vocal continuity, loudness, or pitch according to therapeutic needs for a particular patient with a voice disorder. For example, for the training of vocal continuity in Visi Pitch, a patient needs to produce a continuous voice to expand a frog's throat until the frog croaks to collect the frog (Figure 1A) and then repeat the task until he or she collects the required number of frogs. For the training of pitch or loudness in Visi Pitch, a patient needs to produce a voice at different levels of pitch or loudness to control a bird to fly to the flowers at different heights (Figure 1B); and then visual feedback, such as size of the frog's throat and height of the bird, is provided in real time so that the patient can maintain his or her voice at a certain level of vocal continuity, loudness, or pitch. The recording and plotting functions of a patient's vocal production time, loudness level, and pitch level during the gameplay in Dr. Speech provide quantitative analysis of a patient's performance for therapists as shown in Figure 2. Vox Systems provides a more advanced vocal continuity training function in which a patient needs not only to produce a continuous voice to allow a game character to cross a street, but also stop voice production to freeze the character if a car randomly passes

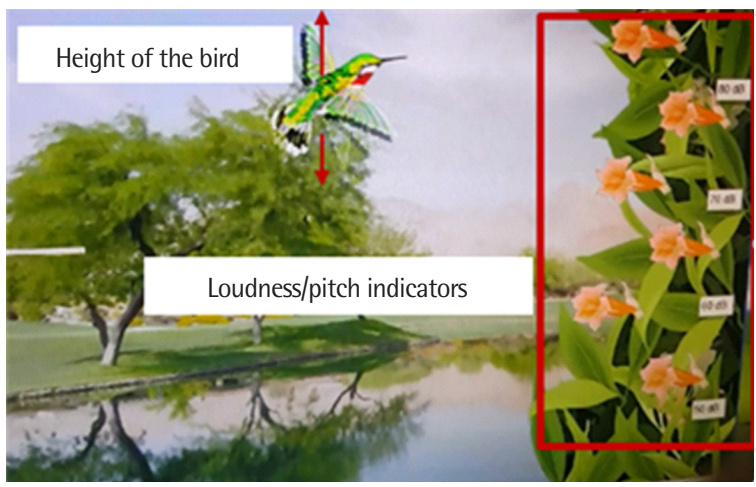

(B)

Figure 1. Vocal training games in Visi Pitch: (A) frog game for vocal continuity training and (B) bird game for vocal loudness/pitch training. 


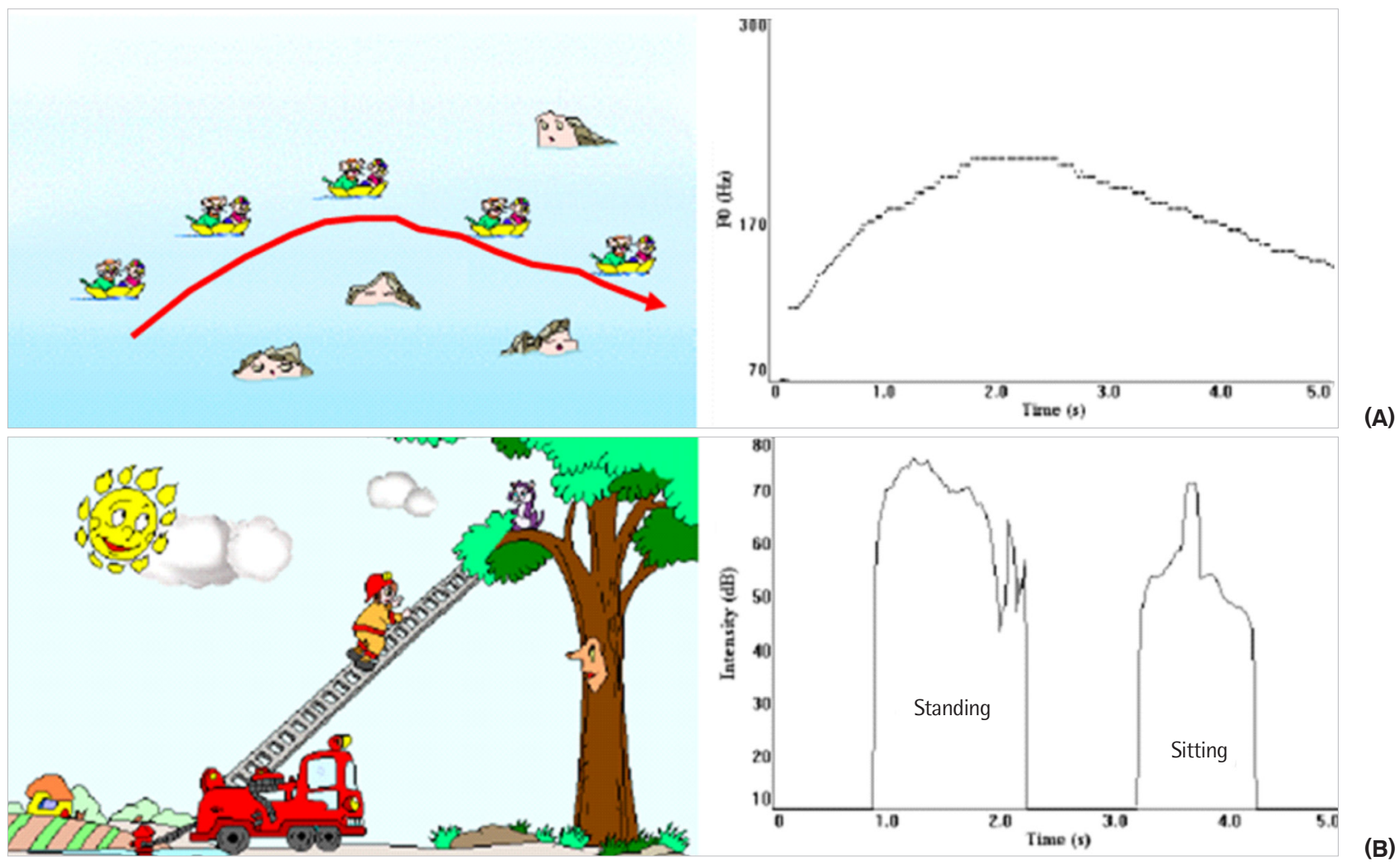

Figure 2. Vocal training games in Dr. Speech: (A) boat game for pitch training and (B) cat rescue game for loudness training with game play time, pitch levels and loudness levels recorded and plotted.
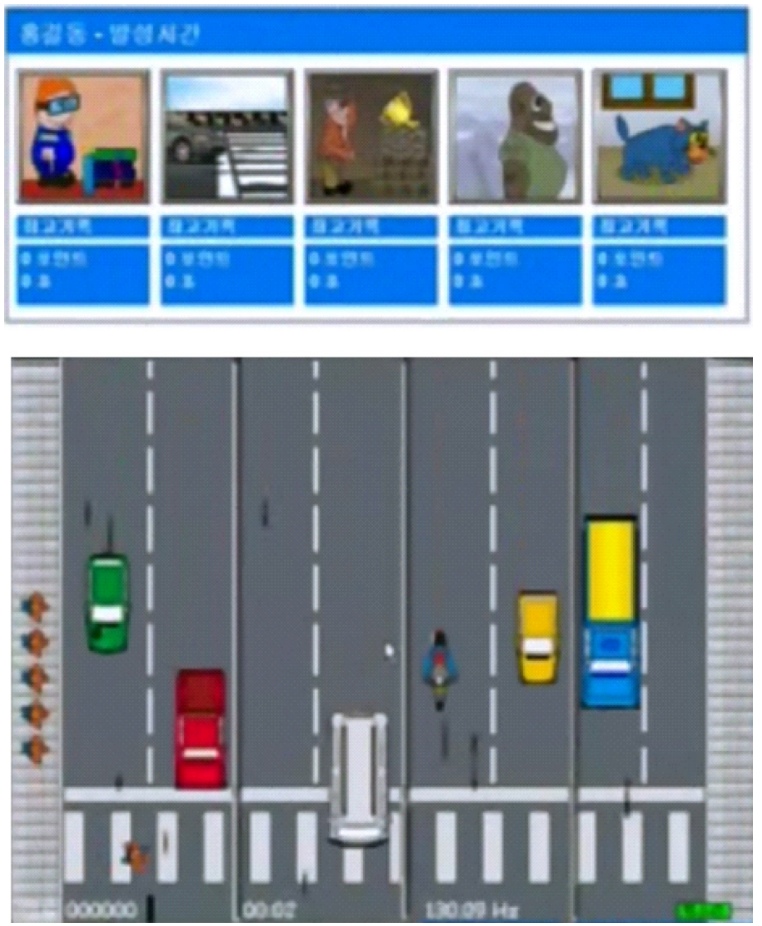

Figure 3. Street crossing game for vocal continuity training in Vox Systems. through as shown in Figure 3. All the features aforementioned are found desirable to the development of a new vocal training game.

\section{Survey of Stakeholder's Needs}

As displayed in Figure 4, the stakeholders' needs survey results indicate that a new vocal training game needs to pay more attention to four (creative freedom, social connectivity, therapy continuity, and customization) user experience scales. Of the game user experience scales, creative freedom (average satisfaction score, 2.5 to 4.3 out of 7 ), social connectivity (2.4 to 4.4 ), customization (2.5 to 5.0 ), and therapy continuity (1.7 to 4.7 ) were found relatively lacking in the three existing games. Furthermore, the therapists suggested providing more games in Vox Systems to keep patients from becoming tired or bored, various difficulty levels in Dr. Speech to maintain patients' motivation, and improving Visi Pitch with modern graphic designs. 


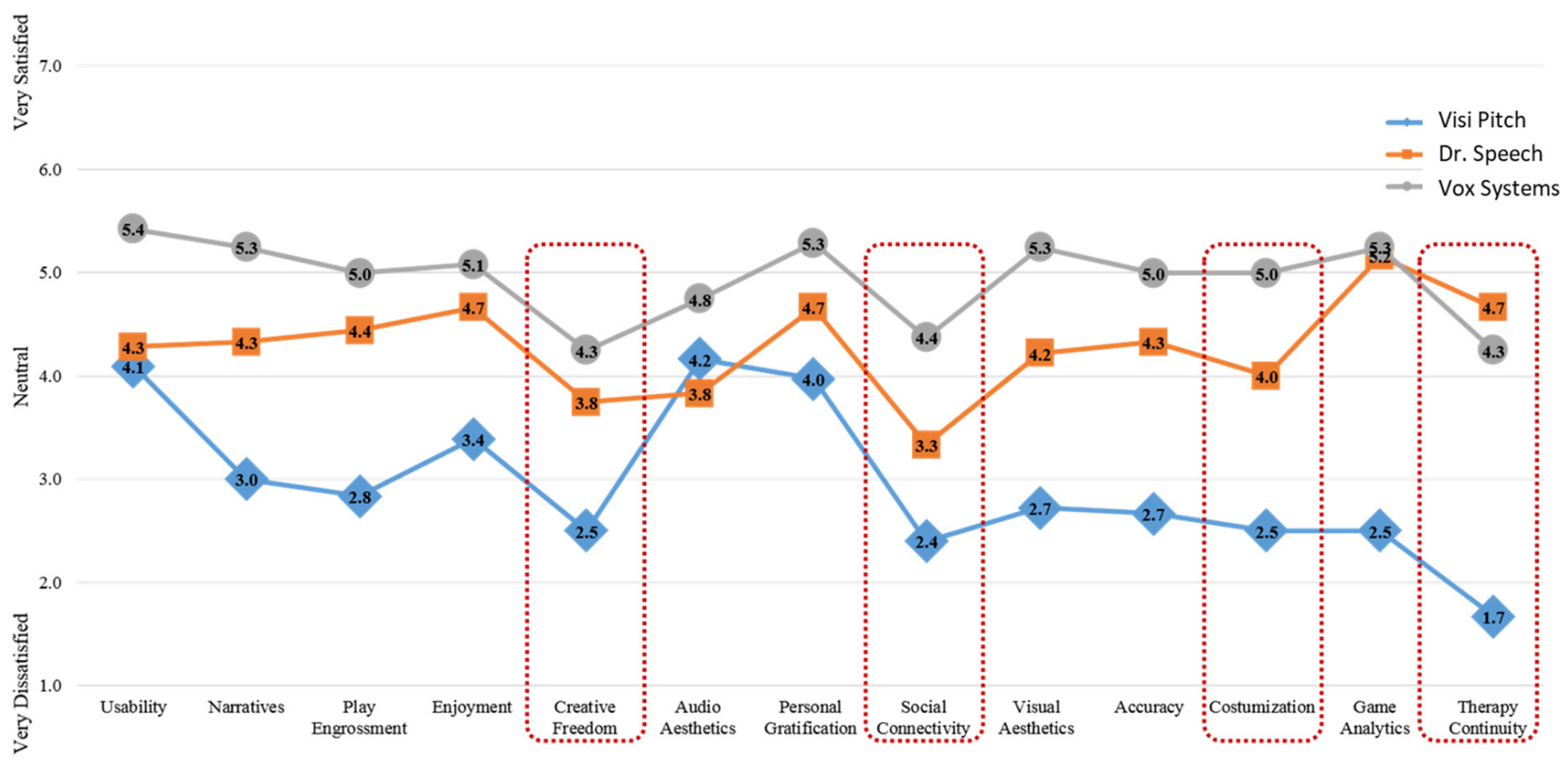

Figure 4. Game user experience satisfaction scores for Visi Pitch, Dr. Speech, and Vox Systems. Game user experience scales which were not commonly satisfied in the three games were indicated by a dotted box.

Table 2. Features of game user experience scales for voice therapy game development

\begin{tabular}{ll}
\hline Scale & \\
\hline Usability & Ease of use \\
& Game mechanics (cause-effect relation) and objectives understanding \\
Garratives & Game story or message should be clear and simple \\
& Various games \\
Play engrossment & Maintain the user's attention \\
Enjoyment & Fun and brings enthusiasm \\
Creative freedom & Several type of environment or object or story \\
Audio aesthetics & Sound effects as a feedback \\
Personal gratification & Reward and obstacle \\
& Difficulty level \\
& Problem-solving strategies \& self-control, skill development \\
Rocial connectivity & Real-time feedback to make user adjust their speech, independence performance \\
Visual aesthetics & Interaction with other player or facilitator (therapist, caretaker) \\
& Appealing graphics (animation) and user interface, adequate information \\
Accuracy & Up-to-date graphics \\
Customization & The accurate interoperation of the input with the game contents (microphone accuracy, less-interference) \\
Game analytics & Depend on user's capability (voice characteristic target (loudness/pitch), duration and repetition) \\
Therapy continuity & Record user data, game played, performance, sound recording \\
& Integration of therapist's (clinic) and patient's system (home)
\end{tabular}

\section{Directions for Serious Game Development}

Detailed features of each scale applicable to vocal training game development are summarized in Table 2. For example, for the scale of social connectivity, a new game needs to provide interaction functions with other players and facilitators (e.g., therapist, parents, and caretakers) by providing a multiplayer module in the 
game for interaction with other players to build social skills for patients.

\section{DISCUSSION \& CONCLUSION}

Thirteen game user experience scales for evaluation of vocal training games were identified based on a literature review. Among the identified scales, nine scales (usability, narratives, play engrossment, enjoyment, creative freedom, audio aesthetics, personal gratification, social connectivity, and visual aesthetics) were adopted from GUESS (Phan et al., 2016) and the four scales (accuracy, customization, game analytics, and therapy continuity) were identified from the review of the other papers to complement the GUESS scales. The game user epxerience scales can be asserted to have content validity because they were extracted from the papers demonstrating their content validity (Phan et al., 2016) and/or corresponding to vocal training games, and they were effectively applied in the present study to the satisfaction evalaution of the vocie training games.

Features applicable to vocal training games were effectively identified in the present study through the benchmarking of the three existing speech training games, including Visi Pitch, Dr. Speech, and Vox Systems. First, vocal training games need to cover the training of vocal continuity, loudness, and pitch. Second, customized difficulty levels, including a target level, training time, and repetition times of vocal continuity, loudness, or pitch can be set in the games according to patients' therapy needs. Third, visual feedback indicating the levels of patients' vocal continuity, loud- ness or pitch is needed in real time; especially for children having difficulties in recognition of their own voice (Pyo, 2013), so that patients can maintain their voice around the target levels to accomplish game tasks. Fourth, recording and plotting functions of patients' vocal production time, loudness and pitch levels during gameplay can be used for quantitative analysis of patients' performance in vocal production. Lastly, game scenarios need to be designed to provide the vocal training of patients at different therapy stages with different disorder levels. For example, a simple game can be provided for a patient at the beginning stage of therapy and then gradually more difficult games can be used for the patient as his or her capability increases.

Game user experience scales which were not commonly implemented in the three existing games were identified through stakeholders' needs survey. Therapists provided relatively low satisfaction scores to the existing games in creative freedom (average satisfaction score, 2.5 to 4.3 ), social connectivity (2.4 to 4.4 ), therapy continuity (1.7 to 4.7 ), and customization (2.5 to 5.0). In particular, they suggested providing games with different scenarios, stories, difficulty levels, and modern graphic designs to maintain patients' motivation, fun, and commitment for better effectiveness of voice therapy games.

Vocal training games need to be developed by applying the features for each of the 13 game user experience scales summarized in Table 2. For example, for therapy continuity, a therapist's system at a clinic and a patient's system at home need to be integrated via a cloud-based system so that the patient can continue vocal training at home after clinical therapy by accomplishing tasks that the

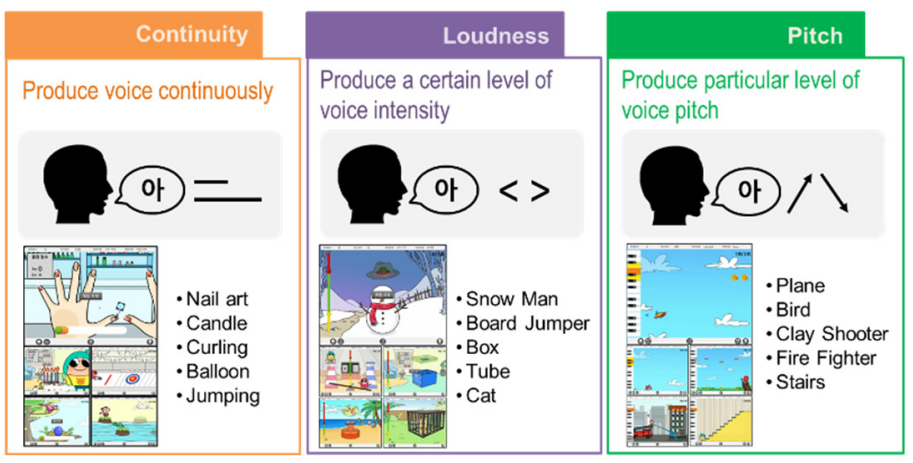

(A)

Figure 5. Examples of new vocal training games: (A) games for continuity, loudness, and pitch training, and (B) a seesaw game requiring a social interaction between a therapist and a patient. 
therapist assigned online.

New serious games for vocal training need to be developed based on the identified stakeholder's needs and the development directions in the present study. Figure 5A shows examples of new games for continuity, loudness, and pitch training and Figure 5B illustrates a seesaw game requiring a patient to imitate the loudness level of a therapist for better social connectivity. New games can be evaluated using the questionnaire established in the present study to compare with the existing games. Furthermore, the identified 13 game user experience scales and the survey of stakeholders' needs can be used for needs analysis and development directions establishment of general serious games. Advanced vocal training serious games need to be implemented as smart device applications and mobile-based contents in the convergence era of information and communication technologies to better satisfy the needs of speech-language pathologists and parents in speech-language intervention for children with communication disorders (Lee, Kim, \& Park, 2016; Yim, Kim, Park, Cheon, \& Lee, 2014).

Lastly, the stakeholder's needs and development directions identified in the present study can be considered in the evaluation of vocal therapy programs based on emerging technologies. Studies including da Silva et al. (2015), Kim and Kwon (2018), Kim et al. (2017), Kim et al. (2019), Lee et al. (2019), and Park et al. (2019) have applied smart devices and virtual reality technologies to assessment and intervention in speech-language pathology. Voice therapy systems based on emerging technologies can be evaluated in terms of the stakeholder's needs identified in the present study and directions of improvement for the advanced technology based systems can be effectively proposed.

\section{REFERENCES}

Bainbridge, K. E., Roy, N., Losonczy, K. G., Hoffman, H. J., \& Cohen, S. M. (2017). Voice disorders and associated risk markers among young adults in the United States. The Laryngoscope, 127(9), 2093-2099.

Batalla, F. N., Márquez, R. G., González, M. B. P., Laborda, I. G., Fernández, M. F., \& Galán, M. M. (2014). Acoustic voice analysis using the Praat programme: comparative study with the Dr. Speech Programme. Acta Otorrinolaringologica (English Edition), 65(3), 170-176.

Black, L. I., Vahratian, A., \& Hoffman, H. J. (2015). Communication disorders and use of intervention services among children aged 3-17 years: United States, 2012 (NCHS Data Brief No. 205). Hyattsville, MD: National Center for Health Statistics.

Bryant, L., Brunner, M., \& Hemsley, B. (2019). A review of virtual reality technologies in the field of communication disability: implications for practice and research. Disability and Rehabilitation: Assistive Technlogy. Advanced online publication. doi: 10.1080/17483107.2018.1549276.

Cagatay, M., Ege, P., Tokdemir, G., \& Cagiltay, N. E. (2012). A serious game for speech disorder children therapy. Proceedings of 2012 7th International Symposium on Health Informatics and Bioinformatics, Nevsehir, Turkey, $18-23$.

Carding, P. N., Roulstone, S., \& Northstone, K. (2006). The prevalence of childhood dysphonia: a cross-sectional study. Journal of Voice, 20(4), 623630 .

Choi, S. H. (2013). Speech-language pathologists' voice assessment and voice therapy practices: a survey for standard clinical guideline and evidencebased practice. Communication Sciences \& Disorders, 18(4), 473-485.

Cohen, S. M., Kim, J., Roy, N., Asche, C., \& Courey, M. (2012). Prevalence and causes of dysphonia in a large treatment-seeking population. The Laryngoscope, 122(2), 343-348.

da Silva, C. A., Fernandes, A. R., \& Grohmann, A. P. (2015). STAR: speech therapy with augmented reality for children with autism spectrum disorders. In J. Cordeiro et al. (Eds.), Enterprise Information Systems (pp. 379396). Cham: Springer.

de Araújo Pernambuco, L., Espelt, A., Balata, P. M. M., \& de Lima, K. C. (2015). Prevalence of voice disorders in the elderly: a systematic review of population-based studies. European Archives of Oto-Rhino-Laryngology, 272(10), 2601-2609.

Faria, V., Abrahão, T., Silva, N., Chagas, V., Nogueira, K., Cardoso, A., \& Lamounier Junior, E. A. (2014). Serious game using augmented reality techniques for the rehabilitation of children with psychomotor disabilities. Proceedings of the 24th Congresso Brasileiro de Engenharia Biomedica (CBEB), Uberlandia, Brazil, 2361-2364.

Grossinho, A., Cavaco, S., \& Magalhães, J. (2014). An interactive toolset for speech therapy. Proceedings of the 11th Conference on Advances in Computer Entertainment Technology, Funchal, Portugal.

Kim, H. J., \& Kwon, S. B. (2018). The effect of augmented reality-based language therapy program on the vocabulary strength improvement in children with language developmental delay. Journal of Speech-Language \& Hearing Disorders, 27(3), 87-96. 
Kim, J., Kim, Y., Park, J., Ban, M., Choi, Y., Nam, Y., Jung B. K., \& Park, J. W. (2017). Evaluation of a smartphone application on vocal rehabilitation in patients with vocal nodules. Proceedings of the Korean Institute of Electrical Engineers Annual Conference, 23-25.

Kim, Y. I., Kwon, S. B., Kwon, S. W., \& Paeng, J. S. (2019). The effect of augmented reality based language therapy program on interrogatives acquisition children with autistic disabilities. Journal of Speech-Language \& Hearing Disorders, 28(2), 155-166.

King, S. N., Davis, L., Lehman, J. J., \& Ruddy, B. H. (2012). A model for treating voice disorders in school-age children within a video gaming environment. Journal of Voice, 26(5), 656-663.

Kostoulas, T., Mporas, I., Kocsis, O., Ganchev, T., Katsaounos, N., Santamaria, J. J., ... \& Fakotakis, N. (2012). Affective speech interface in serious games for supporting therapy of mental disorders. Expert Systems with Applications, 39(12), 11072-11079.

Lee, H. N., Park, J. H., \& Yoo, J. Y. (2019). Development of smartphone-based voice therapy program. Phonetics and Speech Sciences, 11(1), 51-61.

Lee, J. Y., Kim, Y. K., You, H. C., \& Ko, B. W. (2015). An analysis of parents' and experts' needs for smart content for speech and language therapy support for people with speech disorders. Journal of Speech \& Hearing Disorders, 24(4), 171-182.

Lee, Y., Kim, Y. T., \& Park, E. H. (2016). Analysis on current practice and needs based survey of parents and speech-language pathologists for reading intervention with smart device applications. Communication Sciences \& Disorders, 21(3), 502-514.

Marache-Francisco, C., \& Brangier, E. (2016). Validation of a gamification design guide: does a gamification booklet help UX designers to be more creative? In A. Marcus (Ed.), Design, user experience, and usability (pp. 284-293). Cham: Springer.

Martins, R. H. G., do Amaral, H. A., Tavares, E. L. M., Martins, M. G., Gonçalves, T. M., \& Dias, N. H. (2016). Voice disorders: etiology and diagnosis. Journal of Voice, 30(6), 761.e1-761.e9.

Mayer, I. (2012). Towards a comprehensive methodology for the research and evaluation of serious games. Procedia Computer Science, 15, 233-247.

Navarro-Newball, A. A., Loaiza, D., Oviedo, C., Castillo, A., Portilla, A., Lin- ares, D., \& Álvarez, G. (2014). Talking to Teo: video game supported speech therapy. Entertainment Computing, 5(4), 401-412.

Park, H., Kim, G., Lee, Y., Bae, I., \& Kwon, S. (2019). Development and application of augmented reality based vocie therapy software. Proceedings of Spring Conference of the Korean Society of Speech Sciences.

Perry, C. K., Ingrisano, D. R. S., \& Scott, S. R. (1996). Accuracy of jitter estimates using different filter settings on Visi-Pitch: a preliminary report. Journal of Voice, 10(4), 337-341.

Phan, M. H., Keebler, J. R., \& Chaparro, B. S. (2016). The development and validation of the game user experience satisfaction scale (GUESS). Human Factors, 58(8), 1217-1247.

Pyo, H. Y. (2013). A qualitative study on the dysphonia in children: overview, evaluation, and treatment. Communication Sciences \& Disorders, 18(4), 459-472.

Roy, N., Merrill, R. M., Gray, S. D., \& Smith, E. M. (2005). Voice disorders in the general population: prevalence, risk factors, and occupational impact. The Laryngoscope, 115(11), 1988-1995.

Saz, O., Yin, S. C., Lleida, E., \& Rose, R. (2009). Tools and technologies for computer-aided speech and language therapy. Speech Communication, 51, 948-967.

Shtern, M., Haworth, M. B., Yunusova, Y., Baljko, M., \& Faloutsos, P. (2012). A game system for speech rehabilitation. In M. Kallmann \& K. Bekris (Eds.), Motion in games (pp. 43-54). Heidelberg: Springer.

Vicsi, K. (1995). A product-oriented teaching and training system for speech handicapped children. Journal of Microcomputer Applications, 18(4), 287297.

Wattanasoontorn, V., Boada, I., García, R., \& Sbert, M. (2013). Serious games for health. Entertainment Computing, 4(4), 231-247.

Yim, D., Kim, S. Y., Park, W., Cheon, S., \& Lee, Y. J. (2014). Analysis on needs based survey of parents and speech-language pathologists for smartphone programs. Communication Sciences \& Disorders, 19(4), 486-500.

Ziegler, A., \& Hapner, E. (2013). Phonation resistance training exercise (PhoRTE) therapy. In A. Behrman \& J. Haskell (Eds.), Exercises for voice therapy (pp. 147-148). San Diego, CA: Plural. 


\section{발성/구음이 불완전한 대상자용 발성훈련 게임 만족도 및 요구 조사 \\ - 전문가 및 보호자용 -}

먼저 귀하의 소중한 시간을 내어 본 조사에 협조하여 주셔서 깊은 감사를 드립니다.

본 설문지는 발성/구음이 불완전한 대상자의 발성훈련(소리 지속, 크기, 높이 훈련)을 효과적으로 지원하는 기능성 게임 개발을 위해 기존 발성훈련 게임에 대한 전문가 및 부모의 만족도와 요구를 조사하기 위해 작성되었습니다. 본 연구는 전북대학교병원의 의료 기능성 게임 개발사업의 지원을 받아 진행되고 있습니다. 본 설문 응답에 소요되는 시간은 10분 15분입니다. 본 설문의 응답 내용은 연구 목적 이외에 다른 용도로 사용되지 않으며, 응답 내용과 관련된 개인적인 신상이나 의견은 외부에 유출되지 않습니다.

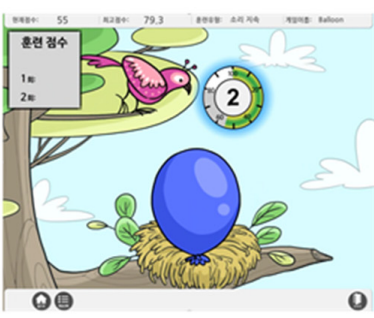

소리 지속 훈련 (소리 지속 시간에 따라 풍선이 커지는 게임)

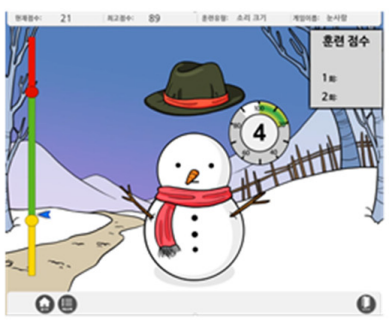

소리 크기 훈련 (소리 크기에 따라 눈사람 모자 크기가 변하는 게임)

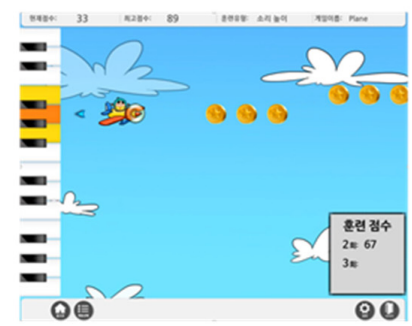

소리 높이 훈련 (소리 높낮이에 따라 비행기 높이가 변하는 게임)

\section{참여자 정보}

생년월일: 년 월 (전문가 경우) 언어치료 경력: 년

성별: ㅁㅏㅏㅏ성ㅁ여성 직무유형:

설문에 참여하신 분들께는 소정의 문화상품권을 email로 발송 드립니다. 행정적인 처리를 위해 아래 정보를 제공해 주시기 바랍니다. 보내 주신 개인정보는 개인정보 보호법을 준수하여 보호될 예정입니다.

성 명: 휴대폰번호:

Email 주소: 
Appendix 1. Continued

\section{I. 발성훈련 게임 사용 경험}

1. 발성훈련 시 게임을 사용한 기간
ㅁ1년 이하
ㅁ 1 2년
ㅁ 2 3년
ㄱ 3 5년
ㄷ년 이상

2. 발성훈련 게임 사용 빈도
ㅁㅓㅓㅇㅢ 사용 안함
ㅁ월 1회 이하
무 1회 이하
무 주 2 회
ㅁㅜㅜ 5 회 이상

3. 발성훈련 게임 운용 시 사용하는 기기
므데스크 탑 PC
ㅁ노트북 PC
므태블릿 PC
므스마트 폰
므스마트 TV

4. 발성훈련 게임 활용 대상 연령
ㅁㅎㄱㄱ령기 이전
ㅁㅎㄱㄱ령기
(0 7세)
(8 18세)
ㅁㅓㅓㅇ년기
(19 29세)
망년기
모년기
(30 59세)
(60세 이상)

\section{II. 발성훈련 게임 평가}

사용하였거나 사용 중인 발성훈련 게임들 중 가장 유용한 게임 정보를 적어 주시기 바랍니다.

게임 제품명

제조회사

사용하는 발성훈련 게임에 사용성에 대해 평가( $\sqrt{ }$ 표기)하여 주시기 바랍니다.

\begin{tabular}{|c|c|c|c|c|c|c|c|c|c|}
\hline No & 세부요소 & $\begin{array}{l}\text { 해당 } \\
\text { 없음 } \\
\end{array}$ & $\begin{array}{l}\text { 매우 } \\
\text { 불만 } \\
\end{array}$ & 불만 & $\begin{array}{l}\text { 약간 } \\
\text { 불만 }\end{array}$ & 보통 & $\begin{array}{l}\text { 약간 } \\
\text { 만족 } \\
\end{array}$ & 만족 & $\begin{array}{l}\text { 매우 } \\
\text { 만족 }\end{array}$ \\
\hline 1 & 게임 방법(규칙)이 배우기 쉽다. & $\square$ & (1) & (2) & (3) & (4) & (5) & (6) & (7) \\
\hline 2 & 게임 조작이 직관적이다. & $\square$ & (1) & (2) & (3) & (4) & (5) & (6) & (7) \\
\hline 3 & $\begin{array}{l}\text { 게임에서 목표(고득점 혹은 성공)를 성취하는 } \\
\text { 방법이 명료하다. }\end{array}$ & $\square$ & (1) & (2) & (3) & (4) & (5) & (6) & (7) \\
\hline 4 & $\begin{array}{l}\text { 게임을 위해 긴 사용설명서를 읽을 필요가 } \\
\text { 없다. }\end{array}$ & $\square$ & (1) & (2) & (3) & (4) & (5) & (6) & (7) \\
\hline 5 & $\begin{array}{l}\text { 게임 메뉴를 사용자가 쉽게 이해하고 사용할 } \\
\text { 수 있다. }\end{array}$ & $\square$ & (1) & (2) & (3) & (4) & (5) & (6) & (7) \\
\hline 6 & $\begin{array}{l}\text { 게임 플레이를 위해 필요한 정보를 적절하게 } \\
\text { 제공한다. }\end{array}$ & $\square$ & (1) & (2) & (3) & (4) & (5) & (6) & (7) \\
\hline 7 & $\begin{array}{l}\text { 게임 플레이 중 화면이나 도움말에서 } \\
\text { 제공되는 정보가 명료하다. }\end{array}$ & $\square$ & (1) & (2) & (3) & (4) & (5) & (6) & (7) \\
\hline 8 & 게임 시나리오(스토리)가 흥미롭다. & $\square$ & (1) & (2) & (3) & (4) & (5) & (6) & (7) \\
\hline 9 & 게임 시나리오(스토리)가 명료하게 이해된다. & $\square$ & (1) & (2) & (3) & (4) & (5) & (6) & (7) \\
\hline 10 & 게임에 몰입하게 한다. & $\square$ & (1) & (2) & (3) & (4) & (5) & (6) & (7) \\
\hline
\end{tabular}

(continued to the next page) 
Appendix 1. Continued

\begin{tabular}{|c|c|c|c|c|c|c|c|c|c|}
\hline No & 세부요소 & $\begin{array}{l}\text { 해당 } \\
\text { 없음 }\end{array}$ & $\begin{array}{l}\text { 매우 } \\
\text { 불만 } \\
\end{array}$ & 불만 & $\begin{array}{l}\text { 약간 } \\
\text { 불만 }\end{array}$ & 보통 & $\begin{array}{l}\text { 약간 } \\
\text { 만족 }\end{array}$ & 만족 & $\begin{array}{l}\text { 매우 } \\
\text { 만족 }\end{array}$ \\
\hline 11 & $\begin{array}{l}\text { 게임을 마치면 다음에 또 게임하는게 } \\
\text { 기다려진다. }\end{array}$ & $\square$ & (1) & (2) & (3) & (4) & (5) & (6) & (7) \\
\hline 12 & 게임하느라 시간 가는 줄 모른다. & $\square$ & (1) & (2) & (3) & (4) & (5) & (6) & (7) \\
\hline 13 & 게임이 재미있다. & $\square$ & (1) & (2) & (3) & (4) & (5) & (6) & (7) \\
\hline 14 & $\begin{array}{l}\text { 게임하는 기회가 주어진다면 또 게임을 하고 } \\
\text { 싶게 한다. }\end{array}$ & $\square$ & (1) & (2) & (3) & (4) & (5) & (6) & (7) \\
\hline 15 & 다른 사람에게도 이 게임을 추천하고 싶다. & $\square$ & (1) & (2) & (3) & (4) & (5) & (6) & (7) \\
\hline 16 & 게임이 상상력을 자극한다. & a & (1) & (2) & (3) & (4) & (5) & (6) & (7) \\
\hline 17 & 게임이 창의성을 돋운다. & $\square$ & (1) & (2) & (3) & (4) & (5) & (6) & (7) \\
\hline 18 & 게임이 호기심을 자극한다. & 口 & (1) & (2) & (3) & (4) & (5) & (6) & (7) \\
\hline 19 & 게임이 독창적이다. & $\square$ & (1) & (2) & (3) & (4) & (5) & (6) & (7) \\
\hline 20 & 게임의 사운드 효과가 게임 내용과 잘 맞는다. & 口 & (1) & (2) & (3) & (4) & (5) & (6) & (7) \\
\hline 21 & 게임의 사운드가 게임하는 재미를 높인다. & a & (1) & (2) & (3) & (4) & (5) & (6) & (7) \\
\hline 22 & $\begin{array}{l}\text { 게임 플레이 시 높은 성취를 하도록 긴장감을 } \\
\text { 유지하게 한다. }\end{array}$ & $\square$ & (1) & (2) & (3) & (4) & (5) & (6) & (7) \\
\hline 23 & 게임에서 과업 완수 시 성취감을 느끼게 한다. & $\square$ & (1) & (2) & (3) & (4) & (5) & (6) & (7) \\
\hline 24 & 레벨을 올리도록 동기 부여가 된다. & $\square$ & (1) & (2) & (3) & (4) & (5) & (6) & (7) \\
\hline 25 & 게임을 통해 발성 훈련 기술 향상 효과가 있다. & $\square$ & (1) & (2) & (3) & (4) & (5) & (6) & (7) \\
\hline 26 & 게임에서 최선을 다하도록 한다. & $\square$ & (1) & (2) & (3) & (4) & (5) & (6) & (7) \\
\hline 27 & $\begin{array}{l}\text { 다른 게임 참여자들과의 사회적 관계를 } \\
\text { 형성하도록 돕는다. }\end{array}$ & $\square$ & (1) & (2) & (3) & (4) & (5) & (6) & (7) \\
\hline 28 & $\begin{array}{l}\text { 부모 혹은 치료사와의 유대 관계를 } \\
\text { 증진시킨다. }\end{array}$ & $\square$ & (1) & (2) & (3) & (4) & (5) & (6) & (7) \\
\hline 29 & 게임 그래픽이 시각적으로 매력적이다. & $\square$ & (1) & (2) & (3) & (4) & (5) & (6) & (7) \\
\hline 30 & 게임 그래픽이 게임 내용과 잘 맞는다. & $\square$ & (1) & (2) & (3) & (4) & (5) & (6) & (7) \\
\hline
\end{tabular}

(continued to the next page) 


\begin{tabular}{|c|l|c|c|c|c|c|c|c|c|}
\hline No & \multicolumn{1}{|c|}{ 세부요소 } & $\begin{array}{l}\text { 해당 } \\
\text { 없음 }\end{array}$ & 매울만 & 불만 & $\begin{array}{l}\text { 약간 } \\
\text { 불만 }\end{array}$ & 보통 & $\begin{array}{l}\text { 약간 } \\
\text { 만족 }\end{array}$ & 만족 & $\begin{array}{l}\text { 매우 } \\
\text { 만족 }\end{array}$ \\
\hline 31 & 게임이 환자를 격려하는 긍정적 기능을 준다. & 口 & (1) & (2) & (3) & (4) & (5) & (6) & (7) \\
\hline 32 & $\begin{array}{l}\text { 소리 입력 신호의 지속시간, 강도, 음도가 } \\
\text { 적절하게 처리되어 게임 컨텐츠와 유기적으로 } \\
\text { 연동한다. }\end{array}$ & 口 & (1) & (2) & (3) & (4) & (5) & (6) & (7) \\
\hline 33 & $\begin{array}{l}\text { 게임 조건(난이도, 반복 등)을 맞춤형으로 } \\
\text { 설정할 수 있다. }\end{array}$ & 口 & (1) & (2) & (3) & (4) & (5) & (6) & (7) \\
\hline 34 & $\begin{array}{l}\text { 게임 결과를 저장하고 체계적으로 관리해 } \\
\text { 준다. }\end{array}$ & 口 & (1) & (2) & (3) & (4) & (5) & (6) & (7) \\
\hline 35 & $\begin{array}{l}\text { 게임 결과를 분석하여 유용한 정량적 정보를 } \\
\text { 제공해 준다. }\end{array}$ & 口 & (1) & (2) & (3) & (4) & (5) & (6) & (7) \\
\hline 36 & $\begin{array}{l}\text { 치료실에서 게임을 활용한 치료 활동이 } \\
\text { 가정에서 연계할 수 있도록 한다. }\end{array}$ & 口 & (1) & (2) & (3) & (4) & (5) & (6) & (7) \\
\hline
\end{tabular}

III. 사용하는 발성훈련 게임에 대한 선호사항, 불편사항, 그리고 개선 방안을 제시하여 주시기 바랍니다.

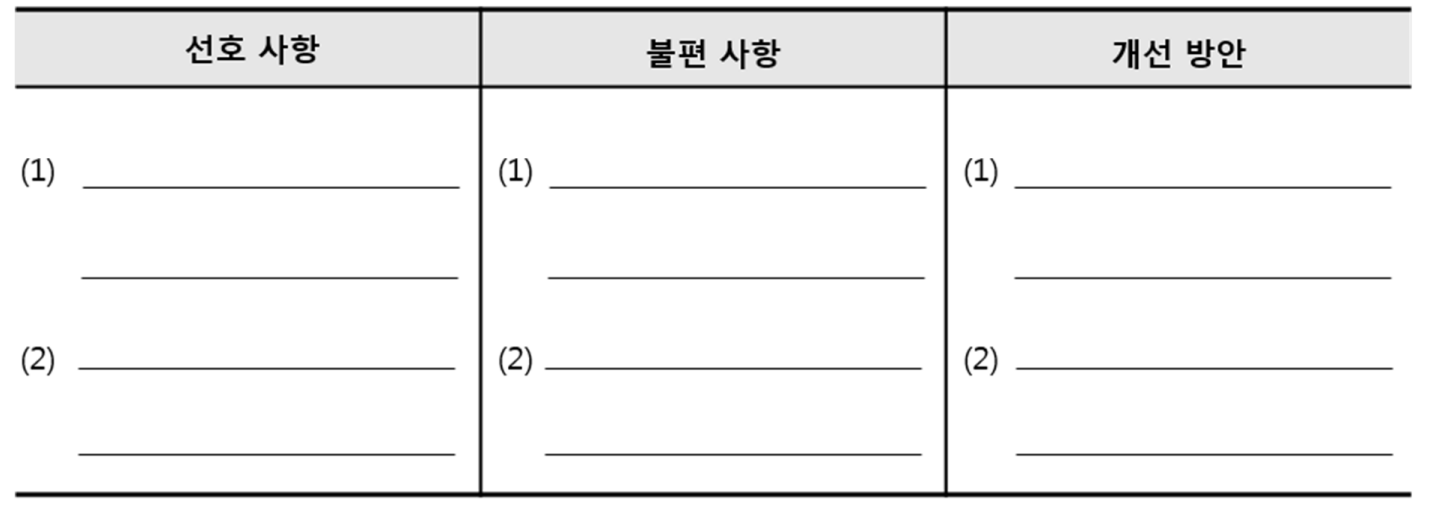




\section{국문초록}

\section{발성훈련 기능성 게임 개발을 위한 기능성 게임 및 이해당사자 요구 분석}

양샤오펑 ${ }^{1}$ 에드위나 사디카 ${ }^{2} \cdot$ 그라디안 프라타마 ${ }^{3} \cdot$ 최영근 $^{2} \cdot$ 김유경 $^{4} \cdot$ 이지윤 ${ }^{5}$ 조윤주 $7.8 \cdot$ 김기욱 $^{8,9} \cdot$ 이진국 $^{9} \cdot$ 유민정 $^{6} \cdot$ 고명환 $^{7,99} \cdot$ 유희천 $^{2}$

${ }^{1}$ Jiangnan University, ${ }^{2}$ 포항공과대학교 산업경영공학과, ${ }^{3}$ Bandung Institute of Technology, ${ }^{4}$ 순천제일대학교 언어재활과, ${ }^{5}$ 제주국제대학교 언어치료학과, ${ }^{6}$ 과학기술일자리진흥원, ${ }^{7}$ 전북대학교 일반대학원 언어치료학과, ${ }^{8}$ 전북대학교 임상의학연구소-전북대학교병원 의생명연구원, ${ }^{9}$ 전북대학교병원 재활의학과

배경 및 목적: 본 연구는 발성훈련에 대한 언어치료 환자의 치료 동기와 참여를 향상시키기 위한 기능성 게임에 대한 요구사항과 개발 방향을 파악하기 위해 수행되었다. 방법: 문헌조사, 이해당사자 요구조사, 기존 3가지 발성훈련 게임(Visi Pitch, Dr. Speech, Vox System)의 벤치마킹 분석이 수행되었다. 결과: 문헌조사를 통해 13 가지 게임 사용자 경험 척도들(유용성, 서사성, 몰입, 즐거움, 창의성, 오 디오 심미성, 개인적 충족감, 사회적 연결성, 시각적 심미성, 정확성, 개인 맞춤형 분석, 게임 분석, 치료 연속성)이 파악되었다. 사용자 경 험 척도들 중 기존 언어치료게임에서 일반적으로 미흡한 속성들로는 창의성(평균 만족도=2.5-4.3; Likert 7점 척도 사용), 사회적 연결 성(2.4-4.4), 치료 연속성(1.7-4.7), 그리고 개인 맞춤형(2.5-5.0)이 파악되었다. 논의 및 결론: 본 연구의 사용자 경험 척도들은 발성훈련 기능성 게임을 평가하는 데 유용하게 활용될 수 있으며, 기존의 게임들이 상대적으로 미흡한 사용성 경험 척도를 보완하는 새로운 기 능성 게임 개발이 필요하다.

핵심어: 기능성 게임, 음성치료, 발성훈련 게임, 사용자 경험

본 논문은 전북대학교병원 의생명연구원과 한국연구재단(No. NRF-2018R1C1B5047805; No. NRF-2018R1A2A2A05023299), 산업통상자 원부(No. 10063384; No. R0004840, 2017)의 지원을 받아 수행된 연구결과임.

\section{ORCID}

양샤오펑(https://orcid.org/0000-0002-5180-109X); 에드위나 사디카(https://orcid.org/ 0000-0001-9037-2569); 그라디안 프라타마(https://orcid.org/0000-0002-6056-5009); 최영근(https://orcid.org/0000-0001-7894-3787); 김유경(https://orcid.org/0000-0002-0772-3151); 이지윤(https://orcid.org/0000-0002-4048-4439); 조윤주(https://orcid.org/0000-0002-1307-8371); 김기욱(https://orcid.org/0000-0002-1628-8382); 이진국(https://orcid.org/ 0000-0002-3383-3258); 유민정(https://orcid.org/ 0000-0002-8983-9878); 고명환(https://orcid.org/0000-0002-0566-3677); 유희천(https://orcid.org/0000-0002-1914-5774) 